\title{
Mechanical Properties Characterization of The Biodegradable Plastic Made from Composite of HDPE (High Density Polyethylene) and Gembolo (Dioscorea bulbifera L.) Starch
}

\author{
Yolanda Harnike Putri Wardani, Suyatno Sutoyo \\ Departement of Chemistry, Faculty of Mathematics and Natural Sciences \\ Universitas Negeri Surabaya \\ Jl. Ketintang Surabaya, Indonesia \\ suyatno@unesa.ac.id
}

\begin{abstract}
It had been conducted research on characterization the mechanical properties of biodegradable plastic composites from HDPE (High Density Polyethylene) and gembolo starch. This study aims to determine the mechanical characteristics of biodegradable plastic made from a mixture of HDPE and gembolo starch. In this study, the variation in HDPE mass ratio with gembolo starch used was $8: 2 ; 7: 3 ; 6: 4 ; 5: 5$; and $4: 6$ grams. The characteristics of biodegradable plastics tested were tensile strength, elongation, Young's modulus measured using Autograph instrument. The results showed that the best tensile strength value was obtained on the ratio of HDPE and gembolo starch of 7: 3 namely 0.6006 $\mathrm{N} / \mathbf{m m}^{2}$, with the elongation and Young modulus of $10.8167 \%$ and $5.5525 \mathrm{~N} / \mathrm{mm}^{2}$, respectively.
\end{abstract}

Keywords - Biodegradable plastic, gembolo starch, HDPE

\section{INTRODUCTION}

Plastics are organic materials that have the ability to be formed in various forms if exposed by pressure and heat. Plastics may be sheets, bars, or blocks, if in the form of products can be food packaging, bottles, food utensils, pipes and so on. The composition of plastic materials are polymers and other additives. Polymers are composed of monomers bound by a chemical bond chain [1].

Plastic material is widely used by the community because it is practical, flexible, lightweight, waterproof, and its price is relatively cheap and affordable. Besides plastic is easily mass-produced. Plastic needs in Indonesia continue to increase to an average increase of 200 tons per year. In 2002 it was recorded 1.9 million tons, in 2003 rose to 2.1 million tons, then in 2004 rose to 2.3 million tons per year. In 2010 2.4 million tons, in 2011 increased to 2.6 million tons [2]. The widespread use of such plastic is due to the extremely high level of community dependency so it can hardly be separated from everyday life including used in food packaging [3].

However, the plastic has a disadvantage that takes 500-1000 years to be decomposed in the soil. The difficulty of the decomposition process resulted in increasing plastic waste and environmental pollution. Plastics are not easily destroyed due to environmental influences such as by the sun, rain, and microbes that live in the soil, so that plastic waste is an environmental issue that must be addressed [4].
The first raw material is synthetic polymer derived from HDPE type plastic, the second material is a natural polymer derived from gembolo starch. Natural polymers have several disadvantages among which are low mechanical properties, not resistant to high temperatures, and fragile. Therefore mixing of synthetic plastics with natural polymers is expected to produce plastics that have high mechanical properties, and can be decomposed by microorganisms [5]. The polymers used in the manufacture of biodegradable plastics are derived from gembolo starch (Dioscorea bulbifera L.), because gembolo are tubers rich in starch and to add value for gembolo and preserve the gembolo. Gembolo contains high carbohydrates $(80.14 \%)$, water $(6.87 \%)$, protein $(4.56 \%)$, fat $(0.46 \%)$, calcium oxalate $(0.28 \%)$, and inulin $(1.61 \mathrm{mg} / \mathrm{g})$ [6].

However, the difference in properties between synthetic plastics and natural polymers, each of which is hydrophobic and hydrophilic, results in a mixture of incompatibilities (not mutually mixed), so that a compatibilizer is required so that both can be mixed perfectly. Addition of the maleic anhydride additive aims to minimize the effect of the different [7]. Gembolo is a starch-rich material and fiber so it is necessary to add plasticizer to get plastic that has good degradation properties and with no lower mechanical properties [8].

Based on the above description, in this research, synthesis and characterization of biodegradable plastic by mixing HDPE synthetic polymer with natural polymer of gembolo starch to improve its physical, mechanical, and degradability. 


\section{MATERIALS AND METHODS}

\section{A. Materials}

Materials used in this research are High Density Polyethylene (HDPE) plastic, gembolo starch, xylene, maleic anhydride, benzoyl peroxide, glycerol, and aqueos.

\section{B. Instruments}

The instruments used in this research is a set of reflux apparatus, thermometer, glassware, 100 mesh sieve, oven, analytical balance, $20 \times 10 \mathrm{~cm}^{2}$ mold, tensile test Autograph AG-10TE Shimadzu, FT-IR, and SEM.

\section{Isolation of Gembolo Starch}

A total of $5 \mathrm{~kg}$ gembolo was cleaned and peeled skin, then cut into small pieces $1 \times 1 \mathrm{~cm}^{2}$, plus water \pm 2.5 liters and then crushed to a coarse porridge. The slurry was added $\pm 1.5 \mathrm{~L}$ of water to extract the pith, then stirred, after which it was filtered and the residue and filtrate was obtained. To increase the starch yield, the residue was added $\pm 1 \mathrm{~L}$ of water, then filtered back until the water was colorless. The filtrate was precipitated \pm 3 hours. The liquid phase was removed by decantation and the starch deposition was taken, then the starch was dried in an oven at $60^{\circ} \mathrm{C}$. at a pressure of $1 \mathrm{~atm}$ for 24 hours to dry. The starch powder was mashed with mortal and sieved with 100 mesh sieve. Then the resulting starch was qualitatively tested using iodine solution [9].

\section{Synthesis of Biodegradable Plastic}

The HDPE was weighed as much as the required mass $(8,7,6,5$, and 4 gram) each mass was put into the reflux device, then $100 \mathrm{~mL}$ xylene solvent was added, then heated at $110^{\circ} \mathrm{C}$. for 1 hour until the polyethylene dissolved. Furthermore, 0.2 gram of benzoyl peroxide was added. After \pm 1 minute, anhydrous maleate added 0.6 gram of gembolo starch was added as needed $(2,3$, 4,5 , and 6 gram) and $4 \mathrm{~mL}$ glycerol was added. After homogeneous mixture, poured into a mold of size $20 \times$ $10 \mathrm{~cm}^{2}$, the solvent was evaporated in the acid room for 1 day and washed at $60^{\circ} \mathrm{C}$. for 24 hours. The results obtained were characterized by autograph instrument.

\section{E. Characterization of Biodegradable Plastic}

\section{- Mechanical Properties}

The test of mechanical properties of the sample includes elongation test and tensile strength test. The plastic film is cut in accordance with ASTMD638 standard as shown in Fig 1.

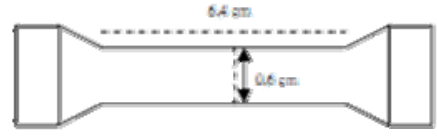

Fig 1. Forms of Specimen for Tensile Strength Test
The test was performed by means of both ends of a plastic film clamped with a tensile test machine. It was noted that the initial length and tip of the recording ink was placed at position 0 on the graph. Then the start knob was switched on and the tool will pull the plastic film until it breaks out and then note the force of tensile strength (F) and the cutoff length. Young elongation and modulus measurements were performed in the same way as the tensile strength test [9].

\section{RESULTS AND DISCUSSION}

\section{A. Isolation of Gembolo Starch}

The gembolo starch isolated from $5 \mathrm{~kg}$ gembolo is dried in an oven at $60^{\circ} \mathrm{C}$ to remove water content. Then the starch is sieved with a 100 mesh sieve to get a fine starch powder. Retrieved $350 \mathrm{~g}$ of white starch. The result of qualitative test on starch occurs that starch had polysaccharide content. This was evidenced by the change of starch color from white to blackish blue by adding the iodine solution. This was because in the starch there were units of glucose that form a helical chain because of the bonding in each unit of glucose. This was what causes the blue-blue color of the complex.

\section{B. Synthesis of Biodegradable Plastic}

In this research the process of making biodegradable plastics was done by grafting method that is mixing between materials that can not mix with insert new functional group. The biodegradable plastics produced in this study were plastics derived from mixtures of HDPE and gembolo starch with the addition of additives such as maleic anhydride, benzoyl peroxide, and glycerol. Polyethylene and gembolo starch were the main ingredients of the mixture for the manufacture of biodegraded plastics. Polyethylene which is a synthetic polymer acts as a major material (matrix), while gembolo starch which is a biodegradable material acts as a minor material. Mixing between starch and polyethylene in the early stages was dissolving HDPE plastic bags in xylene. The dissolution process was carried out by reflux method at $110^{\circ} \mathrm{C}$ for 1 hour until HDPE was dissolved completely. The temperature was maintained until the entire process was complete. The dissolution and grafting process was carried out at $110^{\circ}$ $\mathrm{C}$ [10]. It was found that at $110^{\circ} \mathrm{C}$ the half-life of benzoyl peroxide (BPO) was 18 minutes longer than the AIBN initiator, which was 7 minutes. The shorter the half-life, the initiator generates the radical at that time so that the radicals that would experience the termination reaction so that the grafting process would not occur [10].

In the dissolution process was carried out by reflux method for the dissolution process to run perfectly because the solvent used was easily evaporated so that no solvent was wasted [11]. Soluble HDPE was added BPO and maleic anhydride. The function of adding BPO is to initiate the polymer chain to form free radicals. The 
free radical polymer would react with the added maleic anhydride so that there would be grafted between the polymer and maleic anhydride [12]. The function of addition of maleic anhydride was as a compatibilizer. This was because of the difference between the fundamental properties of starch and HDPE where the starch is polar and hydrophilic, while HDPE is nonpolar and hydrophobic. The presence of maleic anhydride was expected to increase the interaction between HDPE and starch so as to produce compatible polyblend [11]. The next step was the addition of gembolo starch followed by the addition of glycerol as plasticizer. Addition of starch into HDPE serves to trigger the process of biodegradation, because the starch is a natural polymer that is easily broken down by microorganisms. The addition of glycerol as a plasticizer aims to decrease the rigid properties of starch. High fiber content in gembolo cause high intramolecular strength. The addition of plasticizer to starch-based materials can reduce the fragility and high intramolecular strength. The use of glycerol due to glycerol containing the $-\mathrm{OH}$ group is expected to be substituted into starch or can form hydrogen bonding interactions. Changes in this structure would improve the properties of the resulting polybags [12]. Here was the reaction formed between HDPE and starch that has been added the additive shown in Fig 2.

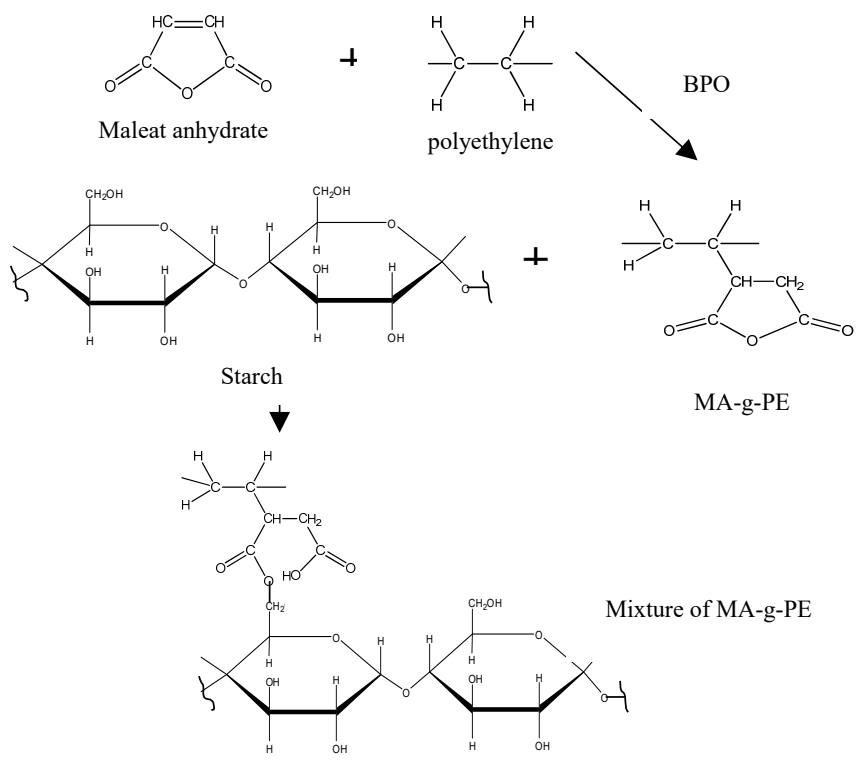

Fig 2. MA-g-PE Bonding Mechanism with Starch

\section{Mechanical Test Results}

Mechanical properties are defined as the sample response to loading and deformation. This property is one of the important properties to know the usefulness of a plastic. The mechanical properties tested in this study include tensile strength, elongation, and Young's modulus. Tensile strength is an indication of the most important strength of a material. Measurement of tensile strength is usually followed by the measurement of elongation breaks (elongation). Elongation is a change in the length of the sample produced by a certain size of the specimen length due to the given force [13]. Elongation is used to determine plastic elasticity. The higher the elongation value the plastic becomes elastic so that the material can be drawn longer, while the plastic with a low elongation value will be fragile [14]. The plastic specimens were characterized by Autograph instruments with ASTM-D638 standard. The results of a complete plastic mechanical properties analysis are presented in Table 1.

TABLE 1. MECHANICAL PROPERTIES OF HDPE AND GEMBOLO STARCH COMPOSITE

\begin{tabular}{|c|c|c|c|c|}
\hline \multicolumn{2}{|c|}{ Composision } & \multirow{2}{*}{$\begin{array}{c}\text { Tensile } \\
\text { Strength } \\
\left(\mathrm{N} / \mathbf{m m}^{2}\right)\end{array}$} & \multirow{2}{*}{$\begin{array}{c}\text { Tensile } \\
\text { Elongation } \\
(\%)\end{array}$} & \multirow{2}{*}{$\begin{array}{c}\text { Modulus } \\
\text { Young } \\
\left(\mathrm{N} / \mathrm{mm}^{2}\right)\end{array}$} \\
\hline $\begin{array}{l}\text { HDPE } \\
\text { (g) }\end{array}$ & $\begin{array}{l}\text { Starch } \\
\text { (g) }\end{array}$ & & & \\
\hline 8 & 2 & 0.5969 & 8.1583 & 7.3615 \\
\hline 7 & 3 & 0.6006 & 10.8167 & 5.6076 \\
\hline 6 & 4 & 0.4473 & 7.5958 & 7.2090 \\
\hline 5 & 5 & 0.3061 & 4.6333 & 6.7305 \\
\hline 4 & 6 & 0.1873 & 3.8792 & 5.0653 \\
\hline $\begin{array}{r}\text { Biod } \\
\text { co }\end{array}$ & $\begin{array}{l}\text { lable } \\
\text { al }\end{array}$ & 0.5766 & 24.2917 & 2.3552 \\
\hline
\end{tabular}

Tensile strength was the maximum stress that the material can bear before the fracture [15]. The presence of starch causes a decrease in the tensile strength value of the mixture. The more the amount of starch added, the smaller the resulting tensile strength. Similarly, the value of elongation also decreased as the number of starch increased. This is consistent with the [4]. Study which states that the higher concentration of starch added, the value of tensile strength and elongation tends to decrease. The decrease in mechanical properties (tensile strength and elongation) due to the addition of starch amounts causes the low surface interaction between the two polymers. However, there is a difference in this study of biodegradable plastics with composition ratio of 8: 2 has a tensile strength value of $0.5969 \mathrm{~N} / \mathrm{mm}^{2}$ and increased in composition ratio of 7: 3 of $0.6006 \mathrm{~N} / \mathrm{mm} 2$ caused by various factors, the only one is the lack of homogeneity at the composition ratio of $8: 2$ so that the grafting process that occurs less than the maximum. Based on the result of testing of the mechanical properties shown in Table 1, the optimum mechanical properties value is on the starch HDPE mixture at 7: 3 ratio with tensile strength value of $0.6006 \mathrm{~N} / \mathrm{mm}^{2}$, the elongation percent value of $10.8167 \%$, and the modulus of Young is $5.6076 \mathrm{~N} / \mathrm{mm}^{2}$. In addition, the values of mechanical properties (tensile strength, elongation, and Young's modulus) of commercial biodegradable plastics were $0.5766 \mathrm{~N} / \mathrm{mm}^{2}, 24.2917 \%$, and $2.3552 \mathrm{~N} / \mathrm{mm}^{2}$ respectively. In this study obtained Young modulus value is quite large compared with the standard set with commercial biodegradable plastic. This is because the mixture of starch acts as a filler (filler) resulting in increased stiffness in the resulting plastic.

\section{CONCLUSIONS}

Based on the result of the research, it can be concluded that the characteristics of biodegradable plastic from composite of HDPE and gembolo starch are best resulted from 7: 3 ratio with tensile strength, elongation and Young 
modulus respectively of $0.6006 \mathrm{~N} / \mathrm{mm}^{2}, 10.8167 \%, 5.6076$ $\mathrm{N} / \mathrm{mm}^{2}$. Biodegradable plastic with a ratio of 7:3 has characteristics that have not met the standard as commercial plastics, but can be degraded by the environment.

\section{ACKNOWLEDGMENT}

Thanks to Mrs. Aniek Setiya Budiatin from Airlangga University for help in testing the tensile strength, elongation, as well as Young's modulus using the Autograph instrument.

\section{REFERENCES}

[1] P. Purwaningrum "Efforts to Reduce Plastic Waste in the Environment" (Upaya mengurangi timbunan sampah plastik di lingkungan). Jurnal Teknik Lingkungan, Vol. 8, No. 2, 141-147. 2016

[2] U. B. Surono. "Various Methods of Converting Plastic Waste Into Fuel Oil". (Berbagai metode Konversi sampah plastik menjadi bahan bakar minyak). Jurnal Teknik Vol. 3, No.1, 2013

[3] P. P. Hidup. Bahaya Bahan Plastik. Mojokerto: PPLH Seloliman. 2007.

[4] Waryat. Rekayasa Proses Produksi Bioplastik Berbahan Baku Pati Termoplastik dan Polietilen. Bogor: Institut Pertanian, 2013

[5] F. W. Billmeyer. Jr. Text Book of Polimer Science. New York: John Willey \& Sons Inc. 1984.

[6] I. P. A. H. A. B. Wibawa "Study on Diversity of Essential Nutriens and Calcium Oxalate Dioscorea on The Islands of Bali and Lombok". (Studi keragaman jenis, kandungan gizi esensial dan kalsium oksalat Dioscorea di pulau Bali dan Lombok). Buletin Kebun Raya, Vol. 14, No. 2, 2011

[7] V. Theresia. Aplikasi dan Karakterisasi Sifat Fisik Mekanik Plastik Biodegrdable dari Campuran LLDPE dan Tapioka. Bogor: Institut Pertanian Bogor, 2003
[8] L. Inggaweni., \& Suyatno. "Characterization of the mechanical properties of biodegradable plastic from high density polyethylene (HDPE) composites and cassava skin starch". (Karakterisasi sifat mekanik plastik biodegradable dari komposit high density polyethylene (HDPE) dan pati kulit singkong). Prosiding Seminar Nasional Kimia, Jurusan Kimia FMIPA UNESA, 3-4 Oktober 2015

[9] Susilawati, Mustafa, I., dan Maulina, Desi. "Biodegradable plastic from a mixture of low density polyethylene (LLDPE) and cassava starch with the addition of acrylic acid". Jurnal Natural. Vol. 11, No. 2, pp: 69-73, 2011

[10] Ghaemy, M. and Roohina, S. "Grafting of maleic anhydride on polyethylene in a homogeneous medium in the presence of radical initiator". Iranian Polymer Journal, Vol.12, No. 11, pp: 21-29, 2003

[11] Mehta, A. K. and Jain, D. Polymer Blends and Alloy Part 1 Compatibilizers a General Survey. www. Plusspolymers.com. Accessed 10 March 2018

[12] Kalambur, S. and Rizvi, S. S. H. "An overview of starch-based plastic blend from reactive extrusion". Journal of plastic Film and Sheeting, Vol 22, No. 1, pp:39-58, 2006

[13] Sundariyani, E., Suyatno. "Edible film synthesis from the blending of Gayam seed starch with chitosan using glycerol plasticizer". (Sintesis edible film dari blending pati biji gayam dengan kitosan menggunakan plasticizer gliserol). Unesa Journal of Chemistry. Jurusan Kimia Universitas Negeri Surabaya., 2017

[14] Shah, A. A., Hasan, F., Hameed, A., \& Ahmed,S. "Biological degradation of plastic: a comprehensive review". Biotechnology Advances. Vol. $26: 246265,2008$

[15] Rizal, Yose. "Analysis of the influence of quench media on the tensile strength of aisi1045 steel". (Analisis pengaruh media quench terhadap kekuatan tarik baja aisi1045). Jurnal APTEK. Vol. 6, No. 2, 183190,2014 